\title{
SPORTS IN THE CASE-LAW OF THE EUROPEAN COURT OF HUMAN RIGHTS
}

\author{
ESPORTES NA JURISPRUDÊNCIA DO TRIBUNAL EUROPEU DE DIREITOS HUMANOS
}

Jakub Czepek ${ }^{1}$

\begin{abstract}
Sport has been an object of interest of international law on several occasions. It has also been a point of interest of regional human rights protection, for example within the legal system of Council of Europe. Recently, the European Court of Human Rights has developed its case-law concerning sport-related issues, such as football supporters related violence and prevention of events of hooliganism, anti-doping related issues or fairness of proceedings before The Court of Arbitration for Sport (CAS) in Lausanne or the protection of professional athletes' rights in the context of anti-doping requirements. The article focuses on the ECtHR case-law relating to sport within the meaning of the right to life (art. 2 of the ECHR), prohibition of torture of inhuman or degrading treatment or punishment (art. 3 of the ECHR), right to liberty and security (art.5 of the ECHR), right to a fair trial (art.6 of the ECHR) or right to protection of private and family life (art. 8 of the ECHR).
\end{abstract}

Keywords: European Court of Human Rights. European Convention on Human Rights. Professional sport. Right to protection of private and family life. Court of Arbitration for Sport.
Resumo: $O$ esporte tem sido objeto de interesse do direito internacional em várias ocasiões. Também tem sido um ponto de interesse da proteção regional dos direitos humanos, por exemplo, dentro do sistema jurídico do Conselho da Europa. Recentemente, o Tribunal Europeu dos Direitos Humanos desenvolveu sua jurisprudência sobre questões relacionadas ao esporte, como a violência relacionada aos torcedores de futebol e a prevenção de eventos de vandalismo, questões relacionadas ao antidoping ou a imparcialidade dos procedimentos perante o Tribunal de Arbitragem do Esporte (CAS) em Lausanne ou a proteção dos direitos dos atletas profissionais no contexto de requisitos antidopagem. $\bigcirc$ artigo tem como objetivo a análise da jurisprudência da $\mathrm{CEDH}$ relativa ao esporte na acepção do direito à vida (art. 2 da CEDH), da proibição de tortura a tratamentos ou penas desumanos ou degradantes (art. 3 da CEDH), do direito à liberdade e à segurança (art.5 da CEDH), direito a um julgamento justo/ a um processo equitativo (art.6 da CEDH) e o direito ao respeito pela vida privada e familiar (art.8 da CEDH).

Palavras-chave: Esporte profissional. Convenção Europeia dos Direitos do Homem. Tribunal Europeu de Direitos Humanos. Tribunal de Arbitragem do Esporte.

\footnotetext{
1 Doctor of Laws from Nicolaus Copernicus University in Toruń, Poland; Professor at Faculty of Law and Administration at Cardinal Stefan Wyszyński University in Warsaw, Poland; ul. Wóycickiego 1/3, bud. 17, 01-938, Warszawa, Poland; https://orcid.org/0000-0001-7741-7806; jjczepek@gmail.com
} 


\section{Introduction}

First of all, it should be noted, that international law of human rights wasn't initially formulated for the sake of sport activities. Other legal instruments are certainly better designed and equipped to serve such purpose. They include: international sport regulations, statutes of particular sport federations or internal legal acts, functioning within States' legal systems.

Available literature concerning this issue presents the autonomous position of sports law in the domestic legal system of any state. Athletes, who are main actors involved in sports, are also subject to regulations concerning clubs, national federations, international federations and the International Olympic Committee (IOC). (Gardiner, 2001; Lapouble, 1999; Lewis, Greenfield, \& Osborn, 2000; Lewis \& Taylor, 2003; Truscan, 2011, p. 308). All sports are also governed by their own rules.

On one hand, human rights protection offers the possibility to protect individuals, such as professional athletes, players, coaches, fans or entities, such as clubs, federations or associations. This protection is still evolving, which is directly linked to the development of human rights protection, which is particularly noticeable in the case-law of European Court of Human Rights (ECtHR).

On the other hand, according to the Olympic Charter, ${ }^{2}$ the practice of sport is - itself - a human right. The Charter states that: "every individual must have the possibility of practicing sport, without discrimination of any kind and in the Olympic spirit, which requires mutual understanding with a spirit of friendship, solidarity and fair play". (Olympic Charter, 2019). This guarantee should be understood together with the idea of Olympism, which places sport "at the service of the harmonious development of humankind, with a view to promoting a peaceful society concerned with the preservation of human dignity". (Olympic Charter, 2019).

The main aim of this article is to present how the European Court of Human Rights refers to the sport-related issues under the European Convention on Human Rights (ECHR). Naturally, the ECHR wasn't primarily designed to focus on this sphere. However, sport related applications may be submitted in the context of particular rights or freedoms protected within the ECHR system. The Convention does not guarantee the right to sport as such. It does not mention sport activities either. Nevertheless, sport related issues seem to be appearing before the Court more and more often. The contexts in which they appear may seem casuistic, but that they derive directly from the applications brought before the Court.

The ECtHR case-law relating to sport focuses on the right to life (art. 2 of the ECHR), prohibition of torture of inhuman or degrading treatment or punishment (art. 3 of the ECHR), right to liberty and security (art.5 of the ECHR), right to a fair trial (art.6 of the ECHR) or right to protection of private and family life (art.8 of the ECHR). These cases aren't numerous, but the fact

\footnotetext{
2 The Olympic Charter, The Olympic Committee. The Charter was first published in 1908, under the title of Annuaire du Comité International Olympique. Currently the version of the Charter is in force since 9.10.2018.
} 
that the Court have published a factsheet concerning sport (Sport and the European Convention on Human Rights, ECtHR Factsheet, 2019) clearly shows that this is also the area of interest of the Court. The above may also suggest that in future, the ECtHR may be developing its case-law concerning sport related issues. The purpose of this article is to present the existing ECtHR case-law in the area of sports.

\section{Sport-related issues and international law of human rights}

Sport had been an object of interest of international law on several occasions. It should be noted that most important legal acts concerning this issue are The Olympic Charter or Code of Sports-related Arbitration, ${ }^{3}$ which is the foundation for the functioning of the Court of Arbitration for Sport $^{4}$ (CAS).

Within the universal system of human rights protection, the most important documents protecting the rights of athletes are classic acts focused on human rights protection, such as International Covenant on Civil and Political Rights (ICCPR, 1966), International Covenant on Economic, Social and Cultural Rights (ICESCR, 1966), Convention on the Rights of the Child (CRC, 1989). Naturally, sport related issues had also been raised by Human Rights Committee, Committee on the Rights of the Child, Committee on Economic, Social and Cultural Rights or Committee on the Elimination of Racial Discrimination. (Truscan, 2011, p. 307). The UN has also developed particular organs focused on sport, such as the United Nations Office on Sport for Development and Peace (UNOSDP), which was introduced in 2001, or The UN Special Adviser on Sport for Development and Peace. Unesco is also focusing on key aspects of sport activities. It includes antidoping, quality of physical education, women in sport related issues. The International Charter of Physical Education and Sport (ICPES, 1978), is a perfect example of the role of Unesco in the area of sport-related issues.

Sport had also been a point of interest of regional human rights protection. The system of Council of Europe (CoE) provides several legal acts concerning sport-related issues. It includes both binding Conventions and soft-law. The most important CoE Conventions in this respect are the Anti-Doping Convention (1989), the Convention on the Manipulation of Sports Competitions (Council of Europe Convention on the Manipulation of Sports Competitions, 2014), the Convention on an Integrated Safety, Security and Service Approach at Football Matches and Other Sports Events (Council of Europe Convention on an Integrated Safety, Security and Service Approach at Football Matches and Other Sports Events, 2014) and the European Convention on Spectator Violence and Misbehaviour at Sports Events and in particular at Football Matches (1985). Most important

\footnotetext{
3 Code of Sports-related Arbitration, Court of Arbitration for Sport. Currently the version of the Charter is in force since 1.1.2017.

4 The Court of Arbitration for Sport was initially established as part of the International Olympic Committee in 1984.
} 
recommendations of Committee of Ministers of Council of Europe, include the Revised Code of Sports Ethics (Committee of Ministers, 2010) or Revised European Sports Charter (Committee of Ministers, 1992).

The exhaustive research concerning sport related issues in the universal system of human rights protection or the system of Council of Europe would not be possible within the limited scope of this article. Such analysis would require a separate research. This is the reason why this article will be focused on the analysis of ECtHR case-law in this area.

\section{Sport related issues in the case-law of European Court of Human Rights}

The wide range of legal acts concerning sport within the system of Council of Europe presents the importance of and the necessity for regulations in these aspects. The case-law of European Court of Human Rights (ECtHR) reflects some of these issues and concern: football supporters related violence and prevention of events of hooliganism, anti-doping related issues or fairness of proceedings before The Court of Arbitration for Sport (CAS) in Lausanne. As it was stressed before, The ECtHR case-law concerning sport related issues focuses on the right to life, prohibition of torture of inhuman or degrading treatment or punishment, right to liberty and security, right to a fair trial or right to protection of private and family life. The Court also referred to sport in relation to other rights and freedoms (Ressiot Others v. France, 2012; Les Authentiks and Supras Auteuil, 2016; Herrmann v. Germany, 2012), ${ }^{5}$ however due to the extent of this article they won't be subjected to a further study.

\section{Right to life and prohibition of torture in the context of sport related issues}

The right to life (art. 2) and prohibition of torture, degrading treatment or punishment (art.3) are fundamental values for human rights protection. As the Court stressed on numerous occasions, within the ECHR system, art. 2 ranks as one of the most fundamental provisions in the Convention -indeed one which, in peacetime, admits of no derogation under art. 15. Together with Article 3 of the Convention, it also enshrines one of the basic values of the democratic societies making up the Council of Europe. (McCann and Others v. The United Kingdom, 1995; Soering v. The United Kingdom, 1989). ${ }^{6}$ However in the sport-related issues, those provisions weren't applied numerously.

\footnotetext{
5 e.g. art. 10 (freedom of expression): ECtHR judgment Ressiot and Others v. France. 28.06.2012. appl. No. 15054/07, 15066/07; article 11 (freedom of assembly and association): ECtHR judgment Les Authentiks and Supras Auteuil 91 v. France. 27.10.2016. appl. No. 4696/11, 4703/11; art. 1 of Protocol No. 1 (protection of property): ECtHR judgment Herrrmann v. Germany. 26.06.2012. appl. No. 9300/07.

6 ECtHR judgment McCann and Others v. The United Kingdom. 27.09.1995, appl. No. 18984/91, \147; ECtHR judgment Soering v. The United Kingdom. 7.07.1989. appl. No. 14038/88, \88.
} 
In the case of Harrison and Others v. The United Kingdom, the Court examined the application concerning the death of 96 football supporters, who were crushed at a football stadium during the match. The crush was a result of overcrowding at the stadium. Inquiries into the deaths ended in a verdict of accidental deaths in all cases. An independent investigation concluded that the main cause of the tragedy had been the failure of police control and that the risks of overcrowding and crushing at the stadium had been known and were foreseeable at the material time. After the release of those information new inquests were ordered and the hearings started. (Harrison and Others v. The United Kingdom, 2014). ${ }^{7}$

The application was brought before the Court by the relatives of the deceased. They complained that the original inquests had been inadequate and that, although new had been ordered, they had been required to wait for over 24 years for an effective investigation concerning the deaths of their relatives. (Harrison and Others v. The United Kingdom, 2014). ${ }^{8}$

The Court noted the faulty character of the previous inquiries and confirmed the existence of state's positive obligations in this respect. ECtHR stated, that it is prepared to accept that the nature of the deaths in the present case engages the procedural aspect of art. 2. It is persuaded that the new findings and the authorities are under an obligation, pursuant to take further investigative measures. (Harrison and Others v. The United Kingdom, 2014). ${ }^{9}$ On the other hand, the ECtHR noticed that a new criminal inquiry has begun and it was investigating allegations of police misconduct in the aftermath of the disaster. (Harrison and Others v. The United Kingdom, 2014). ${ }^{10}$ The steps taken by the authorities were hasty and comprehensive. This is the reason why the ECtHR found the applications premature and declared the application inadmissible. (Harrison and Others v. The United Kingdom, 2014). ${ }^{11}$ It is highly probable, that if the new inquiry would also fail to investigate the case thoroughly, it would open the possibility of lodging further applications before the Court.

The issue of prohibition of torture and the lack of appropriate investigation was analyzed by the ECtHR in the judgment concerning violent actions of police-officers during football match. The case Hentschel and Stark v. Germany concerned two spectators of a football match, who were mistreated by the police. According to applicants, one of them was hit by the truncheon, and the second had pepper spray doused in the face at close range. The police groups consisted of riot control unit. Their uniforms did not include any name tags or other signs identifying the individual officers, they only had an identification number of the squad on the back of the helmets. (Hentschel and Stark v. Germany, 2017). ${ }^{12}$

\footnotetext{
7 ECtHR decision Harrison and Others v. The United Kingdom. 25.03.2014. appl. No. 44301/13, 44379/13, 44384/13, \$2-41.

8 ECtHR decision Harrison and Others v. The United Kingdom. 25.03.2014. appl. No. 44301/13, 44379/13, 44384/13, \$ 45-48.

9 ECtHR decision Harrison and Others v. The United Kingdom. 25.03.2014. appl. No. 44301/13, 44379/13, 44384/13, \$5 53.

10 ECtHR decision Harrison and Others v. The United Kingdom. 25.03.2014. appl. No. 44301/13, 44379/13, 44384/13, \$ 54.

${ }^{11}$ I ECtHR decision Harrison and Others v. The United Kingdom. 25.03.2014. appl. No. 44301/13, 44379/13, 44384/13, \$59.

12 ECtHR judgment Hentschel and Stark v. Germany. 9.11.2017. appl. No. 47274/15, \$ 6-13.
} 
The investigation was twice discontinued by public prosecutor. He found that the inquiry had produced evidence that some of the police officers had used truncheons against spectators, including women and children, in a disproportionate way and without an official order or approval. However, the prosecutor hadn't been neither to establish whether the applicants' injuries had been inflicted by police officers nor to identify the suspects who had allegedly struck and used pepper spray on the applicants. (Hentschel and Stark v. Germany, 2017). ${ }^{13}$

The Court didn't find the violation within the substantive aspect of article 3 . The Court stressed that some evidence confirms the applicants' accounts. However, the ECtHR wasn't able to establish beyond reasonable doubt that the events had happened as it was described by the applicants. (Hentschel and Stark v. Germany, 2017). ${ }^{14}$ It held, however, that there had been a violation of Article 3 of the Convention in its procedural limb. The Court reminded that the inability of eyewitnesses and victims to identify officers alleged to have committed ill-treatment can lead to virtual impunity for a certain category of police officers. Investigation suffering from such a defect cannot be seen as effective. (Hristovi v. Bulgaria, 2011). ${ }^{15}$ Inability to identify masked officers may be counterbalanced by securing all the video footage and its analysis conducted by independent investigating units. (Hentschel and Stark v. Germany, 2017). ${ }^{16}$ However, the Court decided, that investigation deficiencies weren't sufficiently counter-balanced by thorough investigative measures. (Hentschel and Stark v. Germany, 2017). ${ }^{17}$

The ECtHR case-law concerning articles 2 and 3 of the ECHR within the sport-related issues is very modest. However, it concerns an important sphere if protection of an individual during football matches. States' positive obligations in this respect include especially preventive measures considering the spectator's safety and the procedural aspect of effective official investigation in the events of death of mistreatment of an individual. It is vital that responsible state authorities fulfill thoroughly both sets of those positive obligations.

\section{Right to liberty and security in the context of sport-related issues}

Alleged violations of article 5 of the ECHR (right to liberty and security) concern mostly the issue of detaining of an individual in the context of a forthcoming football match in order to prevent the acts of crime and vandalism.

In the judgment Ostendorf v. Germany, the Court analyzed a case of football supporter, who was detained for several hours in police custody in order to prevent him from organizing and taking part in a violent brawl between football hooligans. The applicant was already registered in a

\footnotetext{
${ }^{13}$ ECtHR judgment Hentschel and Stark v. Germany. 9.11.2017. appl. No. 47274/15, \17.

${ }^{14}$ ECtHR judgment Hentschel and Stark v. Germany. 9.11.2017. appl. No. 47274/15, \ 74-78.

15 See ECtHR judgment Hristovi v. Bulgaria. 11.10.2011. appl. No. 42697/05, \92-93.

16 Hentschel and Stark v. Germany, \$ 95-99.

${ }^{17}$ Hentschel and Stark v. Germany, \ 103.
} 
database on persons prepared to use violence in the context of sports events. He was released from the police custody 4 hours later, on the same day, one hour after the football match had ended. (Ostendorf v. Germany, 2013). ${ }^{18}$

According to the Convention standards, being brought to a police station against one's will and being held in a cell amounts to a deprivation of liberty, even if the interference lasted for a relatively short duration of time. (Ostendorf v. Germany 2013). ${ }^{19}$ However, ar. 5.1 c) allows the detention, in the situation when it is reasonably considered necessary to prevent an individual from committing an offence. ${ }^{20}$ According to the Court, the authorities had sufficient facts and information which would satisfy an objective observer that the applicant was planning to arrange and take part in a hooligan brawl, during which concrete and specific criminal offences, namely bodily assaults and breaches of the peace, would be committed. (Ostendorf v. Germany 2013; Shimovolos v. Russia, 2011). ${ }^{21}$

His detention could be classified as effected to prevent him from committing an offence. According to the Court, deprivation of liberty in this situation was justified under art. 5 of the ECHR.

In the case of S., V. and A. v. Denmark, the Court faced a similar problem. Three applicants were detained for 7 hours on the occasion of the football match between Denmark and Sweden, that took place in Copenhagen. Before the event, the police had received intelligence reports of intentions among various club factions from Denmark and Sweden to initiate hooligan brawls. Consequently, an extra 186 police officers were called on duty and the authorities detained the applicants in order to prevent hooligan violence. (S., V. and A. v. Denmark, 2018). ${ }^{22}$

The ECtHR decided that Danish courts had struck the right balance between the applicants' right to liberty and the importance of preventing hooliganism. In its view, less severe measures have to be considered and found to be insufficient to safeguard the individual or public interest which might require that the person concerned be detained. The concrete and specific "offence" referred to under art. 5.1 c) must also be of a serious nature. According to the Court, a hooligan brawl in the center of Copenhagen at, posed considerable danger to the safety of all the peaceful football supporters and uninvolved third parties. The offence which the authorities sought to avert was undoubtedly a serious one. (S., V. and A. v. Denmark, 2018). ${ }^{23}$ ECtHR found that the police actions were proportionate and the detention and police actions didn't cause a violation of art. 5 .

In respect to the art. $5.1 \mathrm{c}$ ), the Court applied a flexible approach in order that the police use of short-term detention to protect the public was not made impracticable. ECtHR stated that the authorities must furnish some facts or information, which would satisfy an objective observer that the person concerned would in all likelihood have been involved in the concrete and specific

\footnotetext{
${ }_{18}$ ECtHR judment Ostendorf v. Germany. 07.03.2013. appl. No. 15598/08, \6-12.

19 ECtHR judment Ostendorf v. Germany. 07.03.2013. appl. No. 15598/08, \ 64.

${ }^{20}$ ECHR. Article 5.1.c).

${ }^{21}$ Ostendorf v. Germany, \80; a contrario ECtHR judment Shimovolos v. Russia. 21.06.2011., appl. No. 30194/09, \55.

22 ECtHR judment S., V. and A. v. Denmark. 22.10.2018. appl. No. 35553/12, 36678/12, 36711/12, \9-20.

${ }^{23}$ ECtHR judment S., V. and A. v. Denmark. 22.10.2018. appl. No. 35553/12, 36678/12, 36711/12, \$161-162.
} 
offence had its commission not been prevented by the detention. Such flexibility also requires that the arrest and detention are "reasonably considered necessary". (S., V. and A. v. Denmark' 2018). ${ }^{24}$

In both cases, The Court found that the preventive detention may be applied in order to prevent acts of football related hooliganism and brawls, during which concrete and specific criminal offences may occur. However, the adopted measures should be proportionate, sufficient and aimed at preventing imminent offences of a serious nature. The hypothetical or highly uncertain threat of football-related hooliganism, without any factual background may not be sufficient to apply the measures like preventive detention. The misuse of this measure may cause a violation of art. 5 .

Spectator violence and safety during football matches is one of the most important sportrelated legal issues in recent years. Since 1985 and the tragic consequences at Heysel Stadium during the European Cup finals, which resulted in 38 deaths and 425 injuries, it became obvious that some effective measures should be taken. As a result of those events, less than 3 months later, the Council of Europe formally adopted the European Convention on Spectator Violence and Misbehaviour at Sports Events and in Particular at Football Matches. (Taylor, 1987).

This fact clearly shows how important is taking effective actions in order to prevent such tragedies from happening. The ECtHR case-law also stresses this necessity. As it was presented in respect to the protection of right to life and freedom form torture, there are clearly expressed state's positive obligations designed to prevent riots, acts of hooliganism, football supporters' brawls and other football-related violent crimes. Preventive detention as a measure of protection from such acts should also be interpreted in the light of states' positive obligations deriving from articles 2 and 3 of the ECHR. Naturally, the use of such measure should be proportionate, necessary in particular situation and should never be misused, especially in any form of arbitrary actions.

\section{Right to a fair trial in professional sport}

The right to a fair trial is one of the most basic first generation human rights and the foundation of the rule of law. It is essential for the protection of human rights and fundamental freedoms. Naturally, sport-related proceedings are also required to meet the standards of article 6 of the ECHR.

In terms of sport-related cases, The ECtHR had an opportunity to verify, if the proceedings before Court of Arbitration for Sport (CAS) in Lausanne comply with the Strasbourg standard deriving from art. 6 . The issue of fair trial guarantees before CAS had already been subjected to a study. (Cernic, 2012, pp. 259-283).

It should be mentioned that the CAS is not part of ordinary court systems. Rather, it was established by the International Olympic Committee as its highest arbitration body for resolving

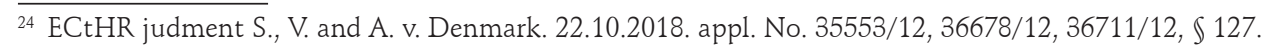


sport related disputes. It appears that it is not entirely clear whether the CAS is a court or merely an arbitration body. It may also be defined as a forum for the world's athletes and sports federations to resolve their disputes through a single independent and accomplished sports adjudication body. (Cernic, 2012, p. 262; McLaren, 2001, pp. 515-542).

In a recent judgment Mutu and Pechstein v. Switzerland, the ECtHR analyzed the applications brought by a professional football player and a professional speed skater. The applicants claimed that the CAS could not be regarded as an independent and impartial tribunal, in the wording of art. 6 of the ECHR. The first applicant complained that the proceedings before CAS lacked of independence and impartiality, on an individual basis, of two arbitrators who composed the arbitration panel in his case. The second applicant claimed that the President of the Panel had a prejudice of against athletes accused of doping and therefore, he lacked impartiality. She also stated, that the CAS could not be considered an independent and impartial tribunal because of a structural problem of imbalance between federations and athletes in appointment of arbitrators. (Mutu and Pechstein v. Switzerland, 2018). ${ }^{25}$

The Court has recalled its previous case-law and reminded that a "court" must always be "established by law". This expression reflects the principle of the rule of law, inherent in the entire system of the Convention and its protocols. (Mutu and Pechstein v. Switzerland, 2018). ${ }^{26}$ The "Court" is characterized in the material sense by its jurisdictional role: to decide, on the basis of legal norms, with full jurisdiction and following an organized procedure, on any question within its jurisdiction. (Sramek v. Austria 1984). ${ }^{27}$ The Court may also be set up to deal with a specific subject matter which can be appropriately administered outside the ordinary court system. (Gustafson v. Sweden, 1997)..$^{28}$ An "independent" Court needs to meet the requirements concerning: the manner of appointment of its members and their term of office, the existence of guarantees against outside pressures and the question whether the body presents an appearance of independence. (Findaly v. The United Kingdom, 1997). ${ }^{29}$ The existence of impartiality for the purposes of art. 6 must be determined according to a subjective test, that is on the basis of the personal conviction of a particular judge in a given case, and also according to an objective test, that is ascertaining whether the judge offered guarantees sufficient to exclude any legitimate doubt in this respect. (Fey v. Austria, 1993).

The above principles deriving from the Court's case-law were applied in respect of CAS proceedings. First of all, the ECtHR has pointed out that art. 6 of the ECHR does not preclude the establishment of arbitral tribunals to try certain disputes of a patrimonial nature. The contractual

\footnotetext{
${ }^{25}$ ECtHR judment Mutu and Pechstein v. Switzerland. 02.10.2018. appl. No. 40575/10, 67474/10, \$9-25.

${ }^{26}$ ECtHR judment Mutu and Pechstein v. Switzerland. 02.10.2018. appl. No. 40575/10, 67474/10, \ 138.

${ }^{27}$ ECtHR judgment Sramek v. Austria. 22.10.1984. appl. No. 8790/79, \36.

${ }^{28}$ ECtHR judgment Gustafson v. Sweden. 01.07.1997., appl. No. 23196/94, \$ 45.

${ }^{29}$ ECtHR judgment Findaly v. The United Kingdom. 25.02.1997. appl. No. 22107/93, \ 73.
} 
clauses of arbitration for the interested parties present undeniable advantages as an administration of justice. (Mutu and Pechstein v. Switzerland, 2018). ${ }^{30}$

The CAS also had a procedure of appointing independent arbitrators. According to the ECtHR, the appointment of one-fifth of independent arbitrators to sports bodies was at the discretion of The International Council of Arbitration for Sport (ICAS). However, ICAS itself was composed entirely of personalities from these bodies, which reveals the existence of a certain link between ICAS and organizations likely to oppose athletes during any disputes brought before the CAS, in particular of a disciplinary nature. Moreover, on the one hand, the arbitrators were appointed for a four-year renewable term and on the other hand, the ICAS had the power to dismiss, any arbitrator refusing or being prevented from performing his duties, or else not performing his duties in accordance with the provisions of the same Code. (Mutu and Pechstein v. Switzerland, 2018). ${ }^{31}$

As to the argument concerning lack of impartiality of the President of the Panel, who allegedly had a prejudice of against athletes accused of doping, the Court didn't find any factual element that could cast doubt on the independence or impartiality of the arbitrator in question. This claim was too vague and hypothetical and was rejected. (Mutu and Pechstein v. Switzerland, 2018). ${ }^{32}$ The accusations of the first applicant concerning impartiality of individual arbitrator, were also dismissed by the Court. (Mutu and Pechstein v. Switzerland, 2018). ${ }^{33}$

Perhaps the analysis of single case does not resolve all the doubts concerning the functioning of the proceeding before the CAS. In Mutu and Pechstein v. Switzerland the Court confirmed the compatibility of the functioning of CAS with the ECHR standards. However in forthcoming case Bakker v. Switzerland (2007), the Court will also have such opportunity.

Article 6 had been also raised in the context of proceedings of a football club before the domestic courts. In the case of FC Mretebi v. Georgia the Court faced an issue of an applicant club concerning the transfer of football player between Georgian and foreign clubs. According to the contract with the footballer, the club should receive large sum of money (1,000,000 Soviet roublesthe equivalent of 6,000 euros) from the footballer's new club-Dinamo FC. In addition, if the footballer was later transferred abroad, the applicant club was to receive $50 \%$ of the international transfer fee owed to Dinamo FC. (FC Mretebi v. Georgia, 2007). ${ }^{34}$

The following percentage of transfer money wasn't transferred to the applicant club. The club was refused an exemption from the court fees by the Georgian Supreme Court. In effect, it had to abandon its cassation appeal as it had been unable to pay the Supreme Court fees. This led to lack of examination of this case. The applicant club complained that it had been denied access to a court.

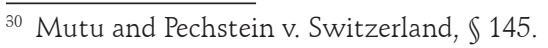

${ }^{31}$ Mutu and Pechstein v. Switzerland, $\$ 154-155$.

${ }^{32}$ Mutu and Pechstein v. Switzerland, \} 1 5 0 .

${ }^{33}$ Mutu and Pechstein v. Switzerland, \$ 161-165.

${ }^{34}$ ECtHr judgment FC Mretebi v. Georgia. 31.07.2007. appl. No. 38736/04, $₫ 7$.
} 
The ECtHR noted, that the Government did not put forward any specific, legitimate aim for the financial restriction on the applicant's right to a court. According to the Court, the fees imposed on the applicant club could not be said to have served either to protect the legitimate interests of the other party against irrecoverable legal costs or to protect the legal system against an unmeritorious appeal. This led to a conclusion that Supreme Court failed to secure a proper balance between the interests of the State in securing reasonable court fees and the interests of the applicant in vindicating its claim through the courts. (FC Mretebi v. Georgia, 2007). ${ }^{35}$ This constituted a violation of art.6 of the ECHR.

As it was already stressed, the proceedings before the CAS may be interesting in the context of the conformity with the Strasbourg standards. The FC Mretebi case clearly proves that the art. 6 requirements should be fulfilled before the domestic courts in relation to professional sport clubs. This is particularly important if the inappropriate fees before the courts may cause a bankruptcy of a club. It is likely, that the importance of sport-related proceedings will increase due to the growth of the sport industry and hefty incomes of a professional athletes. Nevertheless, the current number of such cases seems modest.

\section{Right to respect for private and family life in sport related issues}

Protection of the sphere of privacy has also been analyzed in the contest of anti-doping regulations introduced by World Anti-Doping Agency (WADA). (Pendlebury, 2009, p. 63). In the case FNASS and Others v. France (Fédération Nationale des Associations et Syndicats de Sportifs-National Federation of Sportspersons' Associations and Unions), the Court examined the case concerning anti-doping French regulations, deriving form WADA standards.

The new French law obliged professional athletes to be subjected to particularly intrusive testing system. This system compelled athletes to provide the information concerning their places of residence, training and competition so that they could be located at any time, and to undergo immediate tests ordered on a discretionary basis and without advance notice. The tests could be carried out independently of sporting events and outside training periods, that is, during periods when athletes were no longer at the disposal of their employer but were on holiday, resting or on sick leave or leave following an occupational injury. (FNASS and Others v. France, 2018). ${ }^{36}$

The applicants argued that these regulations infringed their freedom of movement by requiring them to give notice of their whereabouts on an ongoing basis. This included also their non-professional activities, and also infringed their right to a normal family life and their individual freedom as athletes. It also required giving the advance notice of the athletes' schedule, in breach of

\footnotetext{
35 ECtHr judgment FC Mretebi v. Georgia. 31.07.2007. appl. No. 38736/04, \48-49.

${ }^{36}$ FNASS and Others v. France. 18.01.2018. appl. No. 48151/11, 77769/13, \ 11.
} 
the right to establish relationships with their peers and the right to the peaceful enjoyment of their private lives. (FNASS and Others v. France, 2018). ${ }^{37}$

The Court noted that such regulation creates an interference in the sphere of the private and family life. ECtHR also stated that professional athletes are directly concerned by a scourge of doping, which is particularly prevalent in the world of top-level sports in which they compete. In this respect they must accept their fair share of the constraints inherent in the measures needed to combat that issue. (FNASS and Others v. France, 2018). ${ }^{38}$ Recently, a development of increasingly sophisticated doping methods had been noticed and there is very short time-frame within which prohibited substances can be detected. Taking this into account, the Court stated that such requirements should be regarded as reasonably justified, and compliant with the standard of art. 8 of the ECHR. (FNASS and Others v. France, 2018). ${ }^{39}$ Reducing or removing the requirements of which the applicants complained would be liable to increase the dangers of doping to their health and that of the entire sporting community. (FNASS and Others v. France, 2018)..$^{40}$

The Court stated that French regulations didn't cause any violation of art. 8. In this respect, it can be said, that the authorities struck a fair balance between the interest of right to respect for private and family life of athletes and the general interest focused on active and effective anti-doping actions. The above may seem controversial, but such a decision was caused by lack of other reliable methods preventing doping and more advanced doping techniques. The problem of doping in professional sport is an ongoing struggle. The scale of this issue is substantial. This may be confirmed by the systemic character of numerous doping scandals, that came to light in recent years.

\section{Conclusion}

The international protection of human rights relates to sport issues on many occasions. The case-law of ECtHR seems to confirm this statement. Naturally, the Court wasn't created as an organ responsible for settling sport-related issues. However, it is important, that it also guarantees the protection of rights enshrined in the Convention in the sphere of professional sports.

It is wort mentioning, that the sport related issues concern the core human rights enshrined in the Convention. The articles 2 and 3 guarantee the rights that are non-derogable under the art. 15 of the ECHR. Right to liberty and security is often regarded-together with right to life and freedom from torture - as an element of triad of a key Convention guarantees. (Kamiński, 2010, p. 797). Such statement was also confirmed by the Court. (Buzadji v. the Republic of Moldova,

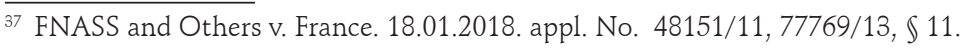

${ }^{38}$ FNASS and Others v. France. 18.01.2018. appl. No. 48151/11, 77769/13, \& 188

${ }^{39}$ FNASS and Others v. France. 18.01.2018. appl. No. 48151/11, 77769/13, \& 190

${ }^{40}$ FNASS and Others v. France. 18.01.2018. appl. No. 48151/11, 77769/13, \ 191.
} 
2016. ${ }^{41}$ Right to a fair trial is also regarded as one of the most basic procedural guarantees. This set of rights is enriched by the right to respect for private and family life.

The fact that sport-related issues appear in the context of most core rights in the ECHR seems very important. This is the reason why the Court notices the existence of both material and procedural positive obligations in the cases concerning sport related issues. In the presented caselaw the existence of such obligations was stressed only in relation to art. 2 and 3 of the ECHR. This fact derives from the paramount importance of right to life and freedom from torture. However, it is possible that the ECtHR will notice the existence of positive obligations in relation to sport issues within the sphere of other rights and freedoms.

The ECtHR case-law relating to sport may seem casuistic. It concerns only few issues that relate to professional sport. These issues concern organization of sports events, spectator violence, short-term detention of football hooligans on the occasion of the football match, compliance of the proceedings before CAS with the standard of a fair trial or the right to respect for private and family life in the context of ongoing anti-doping tests. The amount of problems in this respect isn't very impressive.

However, the number of issues relating sport in the case-law of the ECtHR may increase due to the advanced character of professional sport and its impact on many rights and freedoms guaranteed in the Convention. The fact, that the Court have published a factsheet concerning sport (Sport and the European Convention on Human Rights, ECtHR Factsheet, 2019) stresses the importance of such cases and may suggest that the Court's case-law in this area will be developed in future. The constant growth of sport industry and the complexity of legal issues concerning professional sport may also confirm such necessity.

\section{References}

Anti-Doping Convention. (1989).

Bakker v. Switzerland, pending case. appl. No. 7198/07 (Feb. 13, 2007).

Buzadji v. the Republic of Moldova, appl. No. 23755/07 (July 05, 2016).

Cernic, J. L. (2012). Fair Trial Guarantees before the Court of Arbitration for Sport. (HR\&ILD), $6(2), 259-283$.

Committee of Ministers. (June 16, 2010). Revised Code of Sports Ethics, Recommendation CM/Rec.

\footnotetext{
$\overline{41}$ Buzadji v. the Republic of Moldova. 05.07.2016, appl. No. 23755/07, §84.
} 
Committee of Ministers. (Sept. 24, 1992). Revised European Sports Charter, Recommendation No. R (92) 13 REV.

Convention on the Rights of the Child. (1989).

Council of Europe Convention on an Integrated Safety, Security and Service Approach at Football Matches and Other Sports Events. (2014).

Council of Europe Convention on the Manipulation of Sports Competitions. (2014).

European Convention on Spectator Violence and Misbehaviour at Sports Events and in particular at Football Matches. (1985).

FC Mretebi v. Georgia, appl. No. 38736/04 (July 31, 2007).

Fey v. Austria, appNr No. 14396/88 (Feb. 24, 1993).

Findaly v. The United Kingdom, appl. No. $22107 / 93$ (Feb. 25, 1997).

FNASS and Others v. France, appl. No. 48151/11, 77769/13 (Jan. 18, 2018).

Gardiner, S. (2001). Sports Law. London, UK: Cavendish Publishing.

Gustafson v. Sweden, appl. No. 23196/94 (July 01, 1997).

Harrison and Others v. The United Kingdom, appl. No. 44301/13, 44379/13, 44384/13 (Apr. 03, 2014).

Hentschel and Stark v. Germany, appl. No. 47274/15 (Nov. 9, 2017).

Herrrmann v. Germany, appl. No. 9300/07 (June 26, 2012).

Hristovi v. Bulgaria, appl. No. 42697/05 (Oct. 11, 2011).

International Charter of Physical Education and Sport. (1978). 
International Covenant on Civil and Political Rights. (1966).

International Covenant on Economic, Social and Cultural Rights. (1966).

Kamiński, I. C. (2010). Ograniczenia swobody wypowiedzi dopuszczalne w Europejskiej Konwencji Praw Człowieka. Analiza krytyczna. Warszawa, Poland: Wolters Kluwer.

Lapouble, J.-C. (1999). Droit du Sport. Paris, France: Librairie G6ndrale de Droit et de Jurisprudence.

Les Authentiks and Supras Auteuil 91 v. France, appl. No. 4696/11, 4703/11 (Oct. 27, 2016).

Lewis, A., \& Taylor, J. 2003. Sport: Law and Practice. London, UK: Butterworths LexisNexis.

Lewis, A., Greenfield, S., \& Osborn, G. (Eds.). (2000). Law and Sport in Contemporary Society. London, UK: Franck Cass.

McCann and Others v. The United Kingdom, appl. No. 18984/91 (Sept. 27, 1995).

McLaren, R. H. (2001). Introducing the Court of Arbitration for Sport: The Ad Hoc Division at the Olympic Games. Marquette Sports Law Review (MSLR), 12(515), 515-542.

Mutu and Pechstein v. Switzerland, appl. No. 40575/10, 67474/10 (Oct. 02, 2018).

Olympic Charter. (June 06, 2019). The Olympic Committee.

Ostendorf v. Germany, appl. No. 15598/08 (Mar. 07, 2013).

Pendlebury, A. M. J. (2009). Location, Location, Location: The Whereabouts Rule and the Right to Privacy. Cambrian Law Review (CLR), (40), 63-75.

Ressiot and Others v. France, appl. No. 15054/07, 15066/07 (June 28, 2012).

Shimovolos v. Russia, appl. No. 30194/09 (June 21, 2011).

Soering v. The United Kingdom, appl. No. 14038/88 (July 07, 1989). 
Sport and the European Convention on Human Rights, ECtHR Factsheet. (2019). Retrieved from https://www.echr.coe.int/Documents/FS_Sport_ENG.pdf

Sramek v. Austria, appl. No. 8790/79 (Oct. 22, 1984).

S., V. and A. v. Denmark, appl. No. 35553/12, 36678/12, 36711/12 (Oct. 22, 2018).

Taylor, J. C. (1987). The War on Soccer Hooliganism: The European Convention on Spectator Violence and Misbehaviour at Sports Events. Virginia Journal of International Law (VJIL), 27(3), 603-604.

Truscan, I. (2011). Child Athletes Find Support in Human Rights Law for Tackling Punitive Forms of Training. Human Rights \& International Legal Discourse (HR\&ILD), 6(2), 302-328. 